\title{
Antioxidant Activities of Ribes diacanthum Pall Extracts in the Northern Region of Mongolia
}

\author{
Bayarmaa Birasuren, Hye Lim Oh, Cho Rong Kim, Na Yeon Kim, Hye Lyun Jeon, and Mee Ree Kim ${ }^{\dagger}$ \\ Department of Food \& Nutrition, Chungnam National University, Daejeon 305-764, Korea
}

\begin{abstract}
Ribes diacanthum Pall (RDP) is a member of the Saxifragaceae family. The plant is traditionally used in Mongolia for the treatment of various ailments associated with kidney and bladder's diseases, cystitis, kidney stone, and edema. This study was aimed to investigate antioxidant activities of different solvent extracts of whole Pall plants, based on ferric-reducing antioxidant potential (FRAP), 2,2'-azinobis(3-ethybenzothiazoline-6-sulfonic acid) (ABTS+ ) radical scavenging activity, 1,1-diphenyl-2-picrydrazyl (DPPH·), and hydroxyl $(\cdot \mathrm{OH})$ radical scavenging activities. Additionally, total flavonoids and phenolic contents (TPC) were also detemined. The ethyl acetate extract of RDP (EARDP) had a remarkable radical scavenging capacity with an $\mathrm{IC}_{50}$ value of $0.1482 \mathrm{mg} / \mathrm{mL}$. In addition, EARDP was shown to be higher in total phenolic and flavonoid contents than the methanol extract of RDP (MRDP). Moreover, the EARDP had the predominant antioxidant capacity, DPPH, hydroxyl, and ABTS radical scavenging activities and ferric reducing power. These results suggest a potential for $R$. diacanthum Pall extract as a functional medicinal material against free-radical-associated oxidative damage.
\end{abstract}

Key words: Ribes diacanthum Pall, phenols, flavonoid, antioxidant activity

\section{INTRODUCTION}

Ribes diacanthum Pall (RDP) (Mongolian: Thehiin Sheeg) is a native Mongolian medicinal plant belonging to the Saxifragaceae family, which is widely distributed throughout the Northern Mongolian regions, Khangai, Khentii, Great Khingan, Mongol Daguur and East-Mongolia. RDP is the most important plant for Mongolians as it provides many versatile uses. In traditional Mongolian medicines, the aerial parts (leaves, stem, and fruits) of RDP have been used for the treatment of kidney diseases such as cystitis, and bladder infections, retention, and edema. The aqueous extract of this plant has been shown to control kidney stones, stimulate the diuretic effect, and improve choroid plasticity (1). Generally, plants contain a variety of phytochemicals, the consumption of which has been correlated with positive regulatory effects in human health $(2,3)$. Oxidative stress occurs from an imbalance between the antioxidant defense systems and the formation of reactive oxygen species (ROS), and may damage essential biomolecules such as proteins, DNA, and lipids. Oxidative damage may cause cellular injuries and death, and exacerbate several degenerative diseases associated with aging, including cancer, cardiovascular disease, atherosclerosis, and neurodegeneration (4-7). Phenolic compounds and flavonoids are also widely distributed in plants and have been reported to exert multiple biological effects, including potential antioxidant activities $(8,9)$, anti-inflammatory and anti-carcinogenic activities (10); moreover, these compounds inhibit the oxidation of lipids and prevent oxygen-induced cellular damage in the body (11). Recently, many researchers have focused on the safety of food and functional characteristics on human health, such as antioxidant properties (12). Thus, the natural antioxidants present in medicinal and food plants that may help attenuate oxidative stress are growing in interest (13). Traditional medicines are used throughout the world and plants still represent a large source of natural antioxidants that may serve as leads for the development of novel drugs $(4,14)$. About 975 species are registered as medicinal plants, which are used in folk and traditional medicines of Mongolia and boundary countries, including 200 species that are used in modern medicine (1). Since $R$. diacanthum Pall has been clinically used in Mongolia for a long time, the effort to find naturally-occurring active compounds from Mongolian medicinal plants is worthwhile. However, the antioxidant activities of $R$. diacanthum Pall have not been previously reported.

In this study, we investigated antioxidant activities of different solvent extracts from $R$. diacanthum Pall by assessing total phenolic and flavonoid contents, as well as DPPH, hydroxyl and ABTS radical scavenging activ- 
ities, and FRAP. The assessment of antioxidant activities of $R$. diacanthum Pall will help to understand its pharmacological effects for improving human health.

\section{MATERIALS AND METHODS}

\section{Chemicals}

1,1-Diphenyl-2-picrylhydrazyl (DPPH), 2,2'-azinobis (3-ethylbenzothiazoline-6-sulfonic acid (ABTS) diammonium salt, 2,4,6-tri(2-pyridyl-s-triazine (TPTZ), sodium bicarbonate, 2-deoxy-D-ribose, trichloroacetic acid (TCA), Folin \& Ciocalteu's phenol reagent, naringin, L-ascorbic acid, $\alpha$-tocopherol, and butylated hydroxylanisole (BHA) were purchased from Sigma-Aldrich Co. (St. Louis, MO, USA). Tannic acid was obtained from Yakuri Pure Chemicals Co., Ltd. (Kyoto, Japan). All organic solvents and chemicals used in this study were of analytical grade.

\section{Sample preparation}

The aerial parts (leaves, stems, and fruits) were collected from fresh $R$. diacanthum Pall plants in the Khentii Mountains located in the Northern regions of Mongolia from August to September in 2011. The plant specimens were authenticated and deposited in the Botany Herbarium of the Department of Biology, Ulaanbaatar University of Mongolia. The plants were cleaned and air-dried under shade. The dried samples were stored at $-70^{\circ} \mathrm{C}$ until used.

\section{Preparation of extract}

The dried aerial parts of Ribes diacanthum Pall plants $(2 \mathrm{~kg}$ ) were exhaustively extracted with $9 \mathrm{~L}$ of $80 \%$ methanol for 30 days at room temperature. Samples (20 g) were then extracted with water and $80 \%$ ethanol $(1000$ $\mathrm{mL}$ ) at room temperature for 21 days. The residual materials were re-extracted by the same procedure (3 times). The extracts were filtered over filter paper (No. 3, Whatman International Limited, Kent, England), and the filtrate was evaporated by a rotary evaporator (N11, Yamato Co., Tokyo, Japan) under reduced pressure at a temperature lower than $40^{\circ} \mathrm{C}$. The residue was dissolved in distilled water $(200 \mathrm{~mL})$ and then extracted with ethyl acetate $(1 \mathrm{~L})$ using a separating funnel. The ethyl acetate layer was collected and evaporated to dryness in a vacuum to yield the ethyl acetate $(41 \mathrm{~g})$ fractions. The dried samples were dissolved in respective solvents and filtered with a $0.45 \mu \mathrm{m}$ membrane filter (Millipore, Billerica, MA, USA). The positive controls ( $\alpha$-tocopherol, BHA, butylated hydroxyanisole) and each solvent extract (MRDP, EARDP, WRDP, ETRDP) were dissolved in methanol to the concentration of $100 \mathrm{mg} / \mathrm{mL}$ as stocks. All samples were placed in a glass bottle and stored at $4^{\circ} \mathrm{C}$ until
Aerial parts of Ribes diacanthum Pall - Water extraction 21 days (WRDP, yield: $10.310 \%)$ — 80\% Ethanol extraction 21 days (ETRDP, yield: $11.616 \%)$

$\longleftarrow$ Methanol with water

$80 \%$ Methanol extraction 30 days

- Filtrate

- Evaporation

Methanol extract (MRDP, yield: 13.050\%)

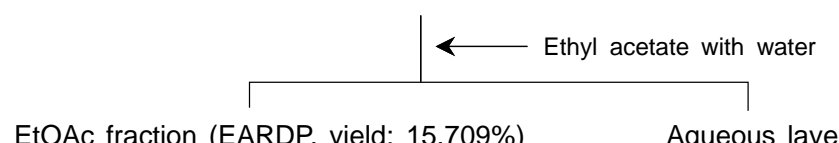

Fig. 1. Procedure to obtain different solvent extracts (MRDP, EARDP, ETRDP, and water) of Ribes diacanthum Pall.

further analyses. The extraction procedure is shown in Fig. 1.

\section{Determination of total phenolics}

Total phenolic contents in each extract were determined with Folin-Ciocalteu reagent according to the method of Singleton (15). The plant sample was dissolved using $20 \mathrm{mM}$ phosphate buffered saline (PBS, $\mathrm{pH}$ 7.4), to a final concentration of $100 \mathrm{mg} / \mathrm{mL}$. An aliquot $(0.33 \mathrm{~mL})$ of the extract was added to a test tube containing $2.5 \mathrm{~mL}$ of distilled water, vortexed, and then mixed with $0.16 \mathrm{~mL}$ of Folin-Ciocalteu reagent. After $5 \mathrm{~min}, 0.3 \mathrm{~mL}$ of $10 \%$ sodium bicarbonate solution was added. The mixture was allowed to stand $30 \mathrm{~min}$ at room temperature in darkness, and the absorbance was measured at $760 \mathrm{~nm}$ (DU650, Beckman Coulter, Brea, CA, USA). A standard curve was prepared to express the results as tannic acid equivalents, i.e. the quantity of tannic acid $(\mathrm{mg} / \mathrm{mL})$.

\section{Determination of total flavonoid contents}

According to the method of Davis (16), total flavonoid contents were determined by preparing $0.4 \mathrm{~mL}$ of extracts in $4.0 \mathrm{~mL}$ of $90 \%$ diethylene glycol and $40 \mathrm{~mL}$ of $1 \mathrm{~N} \mathrm{NaOH}$. The mixture was shaken thoroughly, and allowed to stand for $1 \mathrm{hr}$ at room temperature. The absorbance of the solution was measured at $420 \mathrm{~nm}$. Total flavonoid contents were determined using a standard curve obtained from various concentrations of naringin.

\section{DPPH - radical scavenging activity}

The free radical scavenging activity was carried out according to the Blois method (17) with slight modifications. Methanol solution $(200 \mu \mathrm{L})$ of sample at various concentrations $(0.1 \sim 10 \mathrm{mg} / \mathrm{mL})$ was added to 0.1 $\mathrm{mM}$ methanolic solution of DPPH $(4 \mathrm{~mL})$ and shaken vigorously. The reaction mixture was allowed to stand for $30 \mathrm{~min}$ at room temperature in the dark. The absorb- 
ance of the mixture was determined using a spectrophotometer (DU650, Beckman Coulter) at $517 \mathrm{~nm}$. The antioxidant activity of plant extracts was expressed as $\mathrm{IC}_{50}$, which was defined as the concentration of extract required to inhibit the formation of DPPH radicals by $50 \%$. This activity is given as percent DPPH scavenging that is calculated as: [(control absorbance- extract absorbance)/ control absorbance] $\times 100$. Butylated hydroxylanisole (BHA) and $\alpha$-tocopherol were used as references.

\section{Femic-reducing antioxidant power (FRAP) assay}

The antioxidant capacity of samples was determined according to the Benzie and Strain method (18) with some modifications (19). The method is based on the reduction of the $\mathrm{Fe}^{3+}$-TPTZ complex to the ferrous form at low $\mathrm{pH}$. The fresh working solution (FRAP reagent) was prepared by mixing $25 \mathrm{~mL}$ of $0.3 \mathrm{M}$ acetate buffer, $2.5 \mathrm{~mL}$ of TPTZ solution, and $2.5 \mathrm{~mL}$ of $\mathrm{FeCl}_{3} \cdot 6 \mathrm{H}_{2} \mathrm{O}$ solution, and then warmed (preheated) at $37^{\circ} \mathrm{C}$ before used. A properly diluted sample $(0.1 \mathrm{~mL})$ was added to $4.0 \mathrm{~mL}$ of FRAP reagent to form a mixture. The mixture was incubated at $37^{\circ} \mathrm{C}$ for $10 \mathrm{~min}$ in the dark, and the absorbance was measured at $593 \mathrm{~nm}$ against a blank that was prepared using distilled water. The results, obtained from triplicate analyses, were expressed as aqueous solution of ferrous sulfate $\left(\mathrm{FeSO}_{4} \cdot 7 \mathrm{H}_{2} \mathrm{O}\right)$, and derived from a calibration curve of the standards $(20$ $1,000 \mu \mathrm{M})$. The FRAP values of BHA and $\alpha$-tocopherol were obtained by the same procedure.

\section{ABTS $^{++}$radical scavenging activity assay}

This assay was based on the ability of different substances to scavenge the 2,2'-azinobis(3-ethylbenzothiazoline-6-sulfonic acid) diammonium salts radical cation $\left(\mathrm{ABTS}^{+}\right)$according to the methods of Re et al. (20) with some modifications. The $\mathrm{ABTS}^{+}$stock solution was diluted with ethanol (about 1:88 v/v) to an absorbance of $0.70 \pm 0.02$ at $734 \mathrm{~nm}$ (DU650, Beckman Coulter) for measurement, and equilibrated at $30^{\circ} \mathrm{C}$. Aliquots $(0.1$ $\mathrm{mL}$ ) of the samples were mixed with $2.9 \mathrm{~mL}$ of diluted $\mathrm{ABTS}^{+}$radical solution. After incubation at room temperature for $20 \mathrm{~min}$, the absorbance at $734 \mathrm{~nm}$ was measured. Appropriate solvent blanks were run in each assay. BHA and $\alpha$-tocopherol were employed as positive controls. A lower absorbance of the reaction mixture indicates higher $\mathrm{ABTS}^{+}$radical scavenging activity. The activity is given as percentage $\mathrm{ABTS}^{+}$radical scavenging, which is calculated with the equation:

$\%$ ABTS scavenging activity $=[$ (control absorbance sample absorbance)/ control absorbance $] \times 100$

\section{Hydroxyl radical scavenging activity}

Hydroxyl radical $(\mathrm{OH} \cdot)$ scavenging assay was carried out by measuring the competition between deoxyribose and the extract for hydroxyl radicals generated from the $\mathrm{Fe}^{3+} /$ ascorbate/EDTA/ $\mathrm{H}_{2} \mathrm{O}_{2}$ system (21). Hydroxyl radicals were generated by direct addition of iron (11) salts to the reaction mixture (22). The reaction mixture was prepared with $0.2 \mathrm{~mL}$ of $10 \mathrm{mM} \mathrm{FeSO} \cdot \mathrm{FH}_{2} \mathrm{O}$ containg $10 \mathrm{mM}$ diethylene diamine tetraacetic acid (EDTA), 10 $\mathrm{mM}$ 2-deoxy-D-ribose solution $(0.2 \mathrm{~mL})$, sample solution

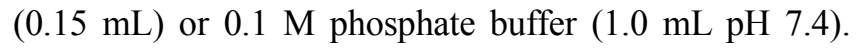
The reaction was initiated by addition of $10 \mathrm{mM} \mathrm{H}_{2} \mathrm{O}_{2}$ $(0.2 \mathrm{~mL})$, followed by incubation at $37^{\circ} \mathrm{C}$ for $4 \mathrm{hr}$. After incubation, $1 \mathrm{~mL}$ of $2.8 \%$ trichloroacetic acid (TCA) and $1.0 \%$ thiobarbituric acid (TBA) were added, and the mixture was heated in boiling water for $10 \mathrm{~min}$. Finally, the reaction mixture was cooled in ice water and centrifuged at $800 \times g$ for $10 \mathrm{~min}$. The absorbance of the supernatant was measured at $532 \mathrm{~nm}$. Each assay was performed in triplicate. Hydroxyl radical scavenging activity was expressed as $50 \%$ inhibitory concentration $\left(\mathrm{IC}_{50}\right)$, which is the concentration to reduce the absorbance of treated samples by $50 \%$ with reference to the control. $\alpha$-tocopherol and BHA were used as the positive controls.

\section{Statistical analysis}

The results are expressed as the mean \pm standard deviation (SD). All statistical analyses were performed using the SPSS 12.0 (Statistical Package for Social, SPSS Inc., Chicago, IL, USA) software. The differences among groups were evaluated by one-way analysis of variance (ANOVA) and Duncan's multiple range tests. A level of $p<0.05$ was used as the criterion for statistical significance.

\section{RESULTS AND DISCUSSION}

\section{Recovery percent, total phenolics, and flavonoids}

Phenolics and flavonoids are important antioxidant substances that are obtained from most natural plants (23). Phenolic compounds in plants constitute a major class of secondary metabolites and have attracted considerable interest due to their scavenging ability on free radicals in the presence of hydroxyl groups (24). Moreover, these compounds possess a broad spectrum of chemical and biological activities including radical scavenging properties (25) and have also been reported to play an important role in stabilizing lipid peroxidation by inhibiting autoxidation of lipids (24). In the present study, the percent yield of total phenolics and flavonoids obtained from aerial parts (leaves, stem, and fruits) of $R$. diacanthum Pall plants using different solvent systems are presented in Table 1.

Ethyl acetate and methanol extractions (15.709 and 
Table 1. Yields and total phenolic and flavonoid contents of different solvent extracts from Ribes diacanthum Pall

\begin{tabular}{lccc}
\hline Sample $^{1)}$ & $\begin{array}{c}\text { Yield } \\
(\%)^{2)}\end{array}$ & $\begin{array}{c}\text { Total phenol } \\
(\text { Tannic } \mathrm{mg} / \mathrm{mL})^{3)}\end{array}$ & $\begin{array}{c}\text { Total flavonoid } \\
(\text { Naringin } \mathrm{mg} / \mathrm{mL})^{4)}\end{array}$ \\
\hline MRDP & 13.050 & $0.136 \pm 0.0005^{5) \mathrm{d}}$ & $0.256 \pm 0.0015^{\mathrm{d}}$ \\
EARDP & 15.709 & $0.488 \pm 0.0005^{\mathrm{a}}$ & $0.995 \pm 0.0005^{\mathrm{a}}$ \\
WRDP & 10.310 & $0.195 \pm 0.0005^{\mathrm{c}}$ & $0.414 \pm 0.0005^{\mathrm{c}}$ \\
ETRDP & 11.616 & $0.236 \pm 0.0005^{\mathrm{b}}$ & $0.835 \pm 0.0473^{\mathrm{b}}$ \\
\hline
\end{tabular}

${ }^{1)}$ Extracts from RDP: MRDP, 80\% methanol; EARDP, ethyl acetate; WRDP, water; and ETRDP, $80 \%$ ethanol.

${ }^{2)}$ Based on weight of aerial parts extracted, Yield $(\%)=($ extract weight/dry weight) $\times 100$.

${ }^{3)}$ Tannic acid was used as a standard for measuring total phenolic contents.

${ }^{4)}$ Naringin was used as a standard for measuring total flavonoid contents.

${ }^{5)}$ Measurements were done in triplicate and values represent mean \pm SD.

${ }^{\mathrm{a}-\mathrm{d}}$ Mean values followed by different superscripts in a column are significantly different by Duncan's multiple range test at $\mathrm{p}<0.05$.

$13.050 \%$ for aerial parts, respectively) followed by ethanol extraction (11.616\% for aerial parts) enhanced the recovery percentage, while water gave the lowest yield. This finding is in agreement with a previous study that reported that higher extraction yields of phenolic compounds were obtained with increasing polarity of the extraction solvent (26). The ethyl acetate extract of RDP contained significantly $(\mathrm{p}<0.05)$ higher amounts of total phenolics $(0.488 \mathrm{mg} / \mathrm{mL})$ than methanol $(0.136 \mathrm{mg} / \mathrm{mL})$, ethanol $(0.236 \mathrm{mg} / \mathrm{mL})$ and water $(0.195 \mathrm{mg} / \mathrm{mL})$ extracts. Similar to the present result, Naczk et al. (27) reported that blueberry leaves had higher amounts of phenolics than the blueberries when extracted by $70 \%(\mathrm{v} / \mathrm{v})$ aqueous acetone and 95\% (v/v) ethanol. Previously, acetone/acetic acid/water mixtures have been shown to extract higher levels of total phenols in black currant buds and leaves (28). The ethanol extract of black currant (Ribes nigrum L.) leaves contained high levels of phenolics, simliarly reported by Vagiri et al. (29). Our results are also similar to Määttä et al. (30) in that green (Ribes nigrum) and white currants (Ribes $x$ Pallidum) had higher amounts of phenolic compounds when compared to other plants within the genus Ribes.

The total flavonoid contents in methanol, ethyl acetate, water and ethanol extracts were $0.256,0.995,0.414$ and $0.835 \mathrm{mg} / \mathrm{mL}$, respectively. Milivojevic et al. (31) reported that besides anthocyanins, the Ribes genus is a rich source of other flavonoids, especially flavonols. Raudsepp et al. (32) have reported the presence of flavonols in black currant leaves. In a recent study, quercetin, myricetin, and kaempferol (aglycones) were reported by Tabart et al. (33) in hydrolyzed extracts of black currant buds and leaves. The flavonols has previously been identified in the leaves of strawberries and raspberries $(34,35)$. Among the phenolic compounds, flavonoids possess biological functions such as anti-inflammatory, anticarcinogenic and cardiovascular protective effects, which may be associated with their antioxidative activity (33, 36). Since the phenolic compounds are considered to be major contributors to the antioxidant capacities of plants, the relatively large phenolic and flavonoid contents in the ethyl acetate crude extract was suggestive for further research on isolating antioxidant compounds.

This study supports our prediction that $R$. diacanthum Pall is a good source of natural antioxidants such as phenolic and flavonoid compounds.

\section{DPPH radical scavenging property}

The DPPH radical is a stable organic free radical with an absorption band at $515 \sim 528 \mathrm{~nm}$, and thus becomes a useful reagent for investigating the free radical scavenging activities of different compounds. The stable DPPH free radicals model can be used to evaluate the antioxidative activities in a relatively short time. The effect of antioxidants on DPPH radical scavenging was thought to occur by its hydrogen donating ability; therefore, the absorbance decreases as a result of a color change from purple to yellow as radicals are scavenged through donation of hydrogen to form the stable DPPH molecule (37). The results on DPPH radical scavenging activities of the methanol (MRDP), ethyl acetate (EARDP), water (WRDP), and ethanol (ETRDP) extracts and the positive control reference standards butylated hydroxylanisole (BHA) and $\alpha$-tocopherol are shown in Table 2. According to the results, as the $\mathrm{IC}_{50}$ value decreases, the antioxidant activity increases. The $\mathrm{IC}_{50}$ value of each extract was compared with BHA $\left(\mathrm{IC}_{50}, 0.068 \mathrm{mg} / \mathrm{mL}\right)$ and $\alpha$-tocopherol $\left(\mathrm{IC}_{50}, 0.048 \mathrm{mg} / \mathrm{mL}\right)$. DPPH radical

Table 2. DPPH radical scavenging activity of different solvent extracts from Ribes diacanthum Pall

\begin{tabular}{|c|c|}
\hline Sample extract ${ }^{1)}$ & $\mathrm{IC}_{50}: \mathrm{mg} / \mathrm{mL}^{2)}$ \\
\hline MRDP & $3.0423 \pm 0.0003^{3) a}$ \\
\hline EARDP & $0.1482 \pm 0.00006^{\mathrm{d}}$ \\
\hline WRDP & $2.0142 \pm 0.00012^{b}$ \\
\hline ETRDP & $1.746 \pm 0.00006^{\mathrm{c}}$ \\
\hline$\alpha$-Tocopherol ${ }^{4)}$ & $0.048 \pm 0.0006^{\mathrm{g}}$ \\
\hline $\mathrm{BHA}^{4)}$ & $0.068 \pm 0.0006^{\mathrm{f}}$ \\
\hline
\end{tabular}

\footnotetext{
${ }^{1)}$ Same extracts as created in Table 1.

${ }^{2)} \mathrm{IC}_{50}(\mathrm{mg} / \mathrm{mL})$, concentration for scavenging $50 \%$ of $\mathrm{DPPH}$ radicals

${ }^{3)}$ Measurements were done in triplicate, and values represent mean \pm SD.

${ }^{\mathrm{a}-\mathrm{f}}$ Mean values followed by different superscripts in a column are significantly different by Duncan's multiple range test at $\mathrm{p}<0.05$.

${ }^{4)} \alpha$-Tocopherol and BHA (butylated hydroxyanisole) were used as positive controls.
} 
scavenging activity of EARDP was found to be higher than those of MRDP. Similar to our result, Amakura et al. (38) reported that blackberries showed the strongest DPPH radical scavenging activity with $\mathrm{EC}_{50}$ value of $2.06 \mathrm{mg} / \mathrm{mL}$, followed by black currant $(2.45 \mathrm{mg} / \mathrm{mL})$ and cowberry $(2.64 \mathrm{mg} / \mathrm{mL})$. According to a well-established thought, antioxidant activities of various vegetables, fruits, and natural plants are attributed to the contents of phenolic compounds (39). Studies by Tabart et al. (40) demonstrated that black currant leaves contained more total phenolic contents than what is found in ripe fruits and that total phenolic contents correlated with antioxidant capacity. The radical-scavenging activity can be related to the presence of the orto-dihydroxy substituted aromatic rings (41).

\section{Determination of reducing power}

Basically, ions can stimulate lipid peroxidation by the Fenton reaction and can accelerate peroxidation by decomposing lipid hydroperoxides into peroxyl and alkoxyl radicals that can themselves abstract hydrogen and perpetuate the chain reaction of lipid peroxidation (42). The simple and reliable FRAP assay measures the reducing potential of an antioxidant reacting with a ferricTPTZ (Fe(III)-TPTZ) complex and producing a colored ferrous-TPTZ (Fe(II)-TPTZ) complex by a reductant at a low pH (about 3.6). The ferric-TPTZ complex can be monitored at $593 \mathrm{~nm}$. A higher absorbance power indicates a higher ferric reducing power. In the present study, the FRAP values for MRDP, EARDP, WRDP and ETRDP are shown in Table 3. The EARDP $(0.591 \mathrm{mmol}$ $\mathrm{Fe}(\mathrm{II}) / \mathrm{mg}$ extract) registered significantly $(\mathrm{p}<0.05)$ higher ferric reducing antioxidant activity than the WRDP $(0.197 \mathrm{mmol} \mathrm{Fe}(\mathrm{II}) / \mathrm{mg}$ extract), indicating that EARDP possesses higher reducing capacity than WRDP. These observations showed that the reducing characteristics of the plants can act as antioxidants, reducing agents, hydrogen donators and oxygen quenchers (43). A direct

Table 3. Ferric-reducing activities of different solvent extracts from Ribes diacanthum Pall

\begin{tabular}{lc}
\hline Sample extract & mmol Fe(II)/mg/extract ${ }^{2)}$ \\
\hline MRDP & $0.465 \pm 0.00006^{3) \mathrm{b}}$ \\
EARDP & $0.591 \pm 0.00006^{\mathrm{a}}$ \\
WRDP & $0.197 \pm 0.00006^{\mathrm{d}}$ \\
ETRDP & $0.444 \pm 0.00006^{\mathrm{c}}$ \\
\hline
\end{tabular}

${ }^{1)}$ Same extracts as created in Table 1.

${ }^{2)}$ Concentration of substance having ferric-TPTZ reducing ability expressed as $\mu \mathrm{mol} \mathrm{Fe}(\mathrm{II})$ equivalents

${ }^{3)}$ Measurements were done in triplicate and values represent mean \pm SD.

${ }^{a-d}$ Mean values followed by different superscripts in a column are significantly different by Duncan's multiple range test at $\mathrm{p}<0.05$. correlation between the antioxidant activity and reducing power of certain plant extracts (44). Small fruits including species of currants, gooseberries, raspberries, blackberries and strawberries are known to contain high levels of antioxidant activities through the FRAP assay (45). Moyer et al. (46) also observed the highest antioxidant capacity in wild plants, especially in the Rubus and Ribes species, using the FRAP assay. The reducing activities are generally associated with the presence of reductones (47), which have been shown to use antioxidant activity to break the free radical chain by donating a hydrogen atom (44). From our results, the reducing ability of Ribes diacanthum Pall, as determined by the FRAP assay and the extent of conjugation of the phenolic compounds, was derived from the presence of phenolics and flavonoids.

\section{Antioxidant activity by the $\mathrm{ABTS}^{+}$assay}

Another stable free radical cation, ABTS, was used to evaluate the antioxidant activity of the methanol and ethyl acetate extracts from Ribes diacanthum Pall. The ABTS systems have been commonly used to measure the total antioxidative status of various biological specimens by measuring radical scavenging through electron donation (48). The ABTS radical scavenging effect of different solvent extracts from $R$. diacanthum Pall exhibited a similar trend to the DPPH radical scavenging activity. The results were expressed as $\mu$ mol Trolox equivalents/g extract. A steady increase was observed in the percentage inhibition of the ABTS radicals by the EARDP, ETRDP, MRDP and WRDP (Fig. 2). The EARDP exhibited higher radical scavenging activity than the WRDP when reacted with the ABTS radicals. As seen

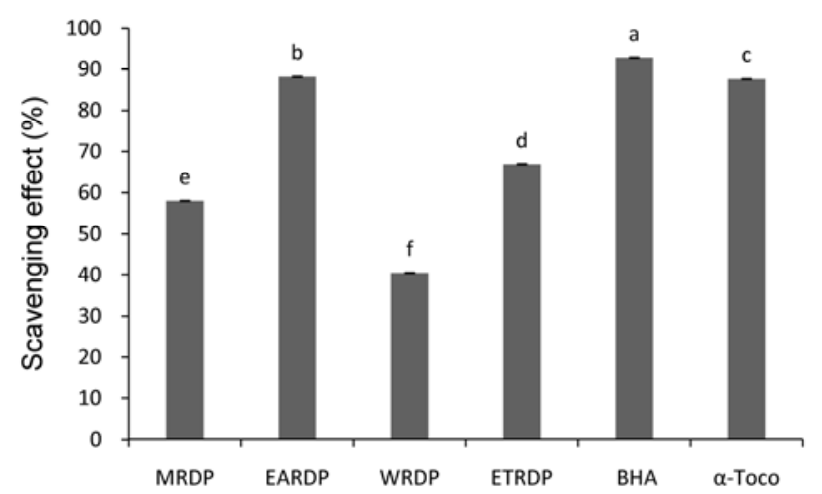

Fig. 2. ABTS radical scavenging activity of different solvent extracts from Ribes diacanthum Pall. Extracts from Ribes diacanthum Pall: MRDP, 80\% methanol; EARDP ethyl acetate; WRDP, water; and ETRDP, $80 \%$ ethanol. Data were presented as mean $\pm S D(n=3)$. ${ }^{a-f}$ Mean values followed by different superscripts in a column are significantly different by Duncan's multiple range test at $\mathrm{p}<0.05$. BHA (butylated hydroxyanisole) and $\alpha$-tocopherol at the concentration of $0.2 \mathrm{mg} / \mathrm{mL}$ were used as positive controls. 
in Fig. 2, the scavenging effect on ABTS radical by dilution concentrations $(0.2 \mathrm{mg} / \mathrm{mL})$ of MRDP, EARDP, WRDP, and ETRDP were found as: $58.002 \%, 88.195 \%$, $40.409 \%$, and $66.876 \%$, respectively. Hagerman et al. (22) have reported that the high molecular weight phenolics (tannins) have a greater ability to quench free radicals $\left(\mathrm{ABTS}^{+}\right)$and their effectiveness depends on the molecular weight, the number of aromatic rings and nature of the hydroxyl groups substitution than the specific functional groups. The position of hydroxyl groups might be more important for mediating potent total antioxidant activity (49). These results indicated that the EARDP contains high amounts of radical scavengers and may be useful as a natural source of antioxidants.

\section{Hydroxyl radical scavenging activity}

Hydroxyl radical $(\mathrm{OH} \cdot)$ is the most reactive and predominant radical generated endogenously during aerobic metabolism to initiate cell damage in vivo (50). Thus, removing $\mathrm{OH} \cdot$ is very important for the protection of living systems. Hydroxyl radical scavenging activity was estimated by generating hydroxyl radicals using ascorbic acid-ion EDTA. The scavenging abilities of MRDP, EARDP, WRDP, and ETRDP of Ribes diacanthum Pall (RDP) are shown in Table 4. The EARDP and ETRDP significantly decreased hydroxyl radical scavenging activity, and $\mathrm{IC}_{50}$ values showed 3.1435 and $4.0709 \mathrm{mg} /$ $\mathrm{mL}$, respectively $(\mathrm{p}<0.05)$. The scavenging ability of the EARDP and ETRDP might be due to the active hydrogen donor ability of hydroxyl substitution. Jason et al. (51) attributed differential genotypic responses to greater increases in hydroxyl radical activity and antioxidant status. This study indicates that EARDP obtained from aerial parts of the traditionally important plant RDP, contains high amounts of phenolics and flavonoid com-

Table 4. Hydroxyl radical scavenging activity of different solvent extracts from Ribes diacanthum Pall

\begin{tabular}{|c|c|}
\hline Sample extract ${ }^{1)}$ & $\mathrm{IC}_{50}: \mathrm{mg} / \mathrm{mL}^{2)}$ \\
\hline MRDP & $5.0025 \pm 0.0005^{3 \mathrm{bb}}$ \\
\hline EARDP & $3.1435 \pm 0.004^{\mathrm{d}}$ \\
\hline WRDP & $5.6525 \pm 0.0006^{\mathrm{a}}$ \\
\hline ETRDP & $4.0709 \pm 0.0006^{c}$ \\
\hline$\alpha$-Tocopherol ${ }^{4)}$ & $0.0049 \pm 0.0001^{\mathrm{f}}$ \\
\hline $\mathrm{BHA}^{4)}$ & $0.0056 \pm 0.00006^{\mathrm{g}}$ \\
\hline
\end{tabular}

${ }^{1)}$ Same extracts as created in Table 1.

${ }^{2} \mathrm{IC}_{50}(\mathrm{mg} / \mathrm{mL})$, concentration for scavenging $50 \%$ of hydroxyl radicals.

${ }^{3)}$ Measurements were done in triplicate and values represent the mean $\pm \mathrm{SD}$.

${ }^{a-g}$ Mean values followed by different superscripts in a column are significantly different by Duncan's multiple range test at $\mathrm{p}<0.05$.

${ }^{4)} \alpha$-Tocopherol and BHA (butylated hydroxyanisole) were used as positive controls. pounds. The high scavenging activity is due to hydroxyl groups existing in the phenolic compounds and their chemical structure that can provide the necessary components as a radical scavenger.

In conclusion, ethyl acetate extract of Ribes diacanthum Pall possessed good antioxidant activities. Although further research is necessary, our study shows that a supplementation with this plant extract could at least help in preventing or decreasing the damages caused by oxidative stress. Based on these data, additional studies are needed to characterize the bioactive compounds responsible for the antioxidative activities in $R$. diacanthum Pall.

\section{ACKNOWLEDGMENTS}

This Research was financially supported by the Women Scientist's Project (Grant 2011-0013606) of Korean Research Foundation.

\section{REFERENCES}

1. Ligaa U, Davaasuren B, Ninjil N. 2006. Medicinal plants of Mongolia used in Western and Eastern medicine. JKC Printing, Ulaanbaatar, Mongolia. p 374.

2. Lampe JW. 2003. Spicing up a vegeterian diet: chemoreceptive effects of phytochemicals. Am J Clin Nutr 78: 579S-583S.

3. Cai Y, Luo Q, Sun M, Corke H. 2004. Antioxidant activity and phenolics compounds of 112 Chinese medicinal plants associated with anticancer. Life Sci 74: 2157-2184.

4. Aruoma OI. 1998. Free radicals oxidative stress, and antioxidants in human health and disease. J Am Oil Chem Soc 75: $199-212$.

5. Ames SN, Shigrenaga MK, Hagen TM. 1993. Oxidant, antioxidant and degenerative disease of aging. Proc Natl Acad Sci USA 90: 7915-7922.

6. Cerutti PA. 1985. Prooxidant status and tumor promotion. Science 227: 379-381.

7. Moskovitz J, Yim KA, Choke PB. 2002. Free radicals and disease. Arch Biochem Biophys 397: 354-359.

8. Salah N, Miller NJ, Paganga G, Tijburg L, Bolwell GP, Rice-Evans C. 1995. Polyphenolic flavanols as scavengers of aqueous phase radicals and as chain-breaking antioxidants. Arch Biochem Biophys 322: 339-346.

9. Silva BM, Andrade PB, Valentaoo P, Ferreres F, Seabra RM, Ferreria MA. 2004. Quince (Cydonia oblonga Miller) fruit (pulp, peel, and seed) and jam: antioxidant activity. J Agric Food Chem 52: 4705-4712.

10. Miller AL. 1996. Antioxidant flavonoids: structure, function and clinical usage. Alt Med Rev 1: 103-111.

11. Tachakittirungrod S, Okonogi S, Chowwanapoonpohn S. 2007. Study on antioxidant activity of certain plants in Tailand: Mechanism of antioxidant action of guava leaf extract. Food Chem 103: 381-388.

12. Sun T, Ho CT. 2005. Antioxidant activities of buckwheat extracts. Food Chem 90: 743-749.

13. Silva EM, Souza JNS, Rogez H, Rees JF, Larondelle Y. 2007. Antioxidant activities and polyphenolic contents of fifteen selected plant species from the Amazonian region. 
Food Chem 101: 1012-1018.

14. Kris-Etherton PM, Lefevre M, Beecher GR, Gross MD, Keen CL, Etherton TD. 2004. Bioactive compounds in nutrition and health-research methodologies for establishing biological function: the antioxidant and anti-inflammatory effects of flavonoids on atherosclerosis. Annu Rev Nutr 24: 511-538.

15. Singleton VL, Rossi JA. 1965. Colorimetry of total phenolics with phosphomolybdic-phosphotungstic acid reagents. Am $J$ Enol Vitic 16: 144-158.

16. Chae SK, Kang GS, Ma SJ, Bang KM, Oh SH, Oh SH. 2002. Standard Food Analysis. Jigu-moonwha Sa, Seoul, Korea. p 381-382.

17. Blois MS. 1958. Antioxidant determinations by the use of a stable free radical. Nature 181: 1199-1200.

18. Benzie IF, Strain JJ. 1996. The ferric reducing ability of plasma (FRAP) as a measure of "antioxidant power": The FRAP assay. Anal Biochem 239: 70-79.

19. Mazar D, Greenberg L, Shamir D, Meyerstein D, Meyerstein N. 2006. Antioxidant properties of bucillamine: Possible mode of action. Biochem Bioph Res Commun 349: 1171- 1175.

20. Re R, Pellegrini N, Proteggente A, Pannala M, Yang M, Rice-Evans C. 1999. Antioxidant activity applying an improved ABTS radical cation decolorizing assay. Free Radical Bio Med 26: 1231-1237.

21. Kunchandy E, Rao MNA. 2002. Oxygen scavenging activity of curcumin. Int $J$ Pharmacog 58: 237-240.

22. Hagerman AE, Riedl KM, Jones GA, Sovik KN, Ritchard NT, Hartzfeld PW, Riechel TL. 1998. High molecular weight plant polyphenolics (tannins) as biological antioxidants. $J$ Agric Food Chem 46: 1887-1892.

23. Xia DZ, Yu XF, Zhu ZY, Zou ZD. 2011. Antioxidant activity and antibacterial activity of six edible wild plants (Sonchus spp.) in China. Nat Prod Res 9: 25-29.

24. Yen GC, Duh PD, Tsai CL. 1993. Relationship between antioxidant activity and maturity of peanut hulls. $\mathrm{J} \mathrm{Am} \mathrm{Oil}$ Chem Soc 41: 67-70.

25. Miliauskas G, Venskutonis PR, Van Beek TA. 2004. Screening of radical activity of some medicinal and aromatic plant extracts. Food Chem 85: 231-237.

26. Javanmardi J. Stushnoff C, Locke E, Vivanco JM. 2003. Antioxidant activity and total phenolic content of Iranian Ocimum accessions. Food Chem 83: 547-550.

27. Naczk M, Grant S, Zademowski R, Barre E. 2006. Protein precipitating capacity of phenolics of wild blueberry leaves and fruits. Food Chem 96: 640-647.

28. Tabart J, Kevers C, Sipel A, Pincemail J, Defraigne JO, Dommes J. 2007. Optimisation of extraction of phenolics and antioxidants from black currant leaves and buds and of stability during storage. Food Chem 105: 1268-1275.

29. Vagiri M, Ekholm A, Andersson SC, Johansson E, Rumpunen K. 2012. An optimized method for analysis of phenolic compounds in buds, leaves, and fruits of black currant (Ribes nigrum L.). J Agric Food Chem 60: 1050110510.

30. Määttä K, Kamal-Eldin A, Törrönen R. 2001. Phenolic compounds in berries of black, red, green, and white currants (Ribes sp.). Antioxid Redox Signal 3: 981-993.

31. Milivojevic J, Slatnar A, Mikulic Petkovsek M, Stampar F, Nikolic M, Veberic R. 2012. The Influence of early yield on the accumulation of major taste and health-related compounds in black and red currant cultivars (Ribes spp.). J Agric Food Chem 60: 2682-2691.
32. Raudsepp P, Kaldmäe H, Kikas A, Libek AV, Püssa T. 2010. Nutritional quality of berries and bioactive compounds in the leaves of black currant (Ribes nigrum L.) cultivars evaluated in Estonia. $J$ Berry Res 1: 53-59.

33. Tabart J, Kevers C, Evers D, Dommes J. 2011. Ascorbic acid, phenolic acid, flavonoid and carotenoid profiles of selected extracts from Ribes nigrum. J Agric Food Chem 59: 4763-4770.

34. Oszmiański J, Wojdylo A, Gorzelany J, Kapusta I. 2011. Identification and characterization of low-molecularweight polyphenols in berry leaf extracts by HPLC-DAD and LC-ESI/MS. J Agric Food Chem 59: 12830-12835.

35. Gudej J, Tomczyk M. 2004. Determination of flavonoids, tannins and ellagic acid in leaves from Rubus L. species. Arch Pharmacol Res 27: 1114-1119.

36. Li WY, Chan SW, Yu PHF. 2007. Correlation between antioxidative power and anticancer activity in herbs from traditional Chinese medicine formulae with anticancer therapeutic effect. Pharmaceutical Biol 45: 541-546.

37. Sancher-Moreno C. 2002. Methods used to evaluate the free radical scavenging activity in foods and biological systems. Food Sci Technol Int 8: 121-137.

38. Amakura Y, Umino Y, Tsuji S, Togogai Y. 2000. Influence of jam processing on the radical scavenging activity and phenolic content in berries. J Agric Food Chem 48: 62926297.

39. Wong PYY, Kitts DD. 2006. Studies on the dual antioxidant and antibacterial properties of parsley (Pertrosselium crispum) and cilantro (Coriandrum sativum) extracts. Food Chem 97: 505-515.

40. Tabart J, Kevers C, Pincemail J, Defraign JO, Dommes J. 2006. Antioxidant capacity of black currant varies with organ, season, and cultivar. J Agric Food Chem 54: 62716276.

41. Cos P, Rajan P, Vedernikova L, Calomme M, Pieters L, Vlietinck AJ, Augustyns K, Haemers A, Berghe DV. 2002. In vitro antioxidant profile of phenolic acid derivatives. Free Radic Res 36: 711-716.

42. Halliwell B, Gutteridge JMC. 1996. Free radicals, ageing, and disease. In Free Radicals in Biology and Medicine. Clarendon Press, London, UK. p 416-423.

43. Wayne PA. 2002. NCCLS. Performance standards for antimicrobial susceptibility testing. $12^{\text {th }}$ informational supplements. NCCS document. M100-512.

44. Gordon MF. 1990. The mechanism of antioxidant action in vitro. In Food Antioxidants. Hudson BJF, ed. Elsevier, London, UK. p 1-18.

45. Henríquez C, Carrasco-Pozo C, Gómez M, Brunser O, Speisky H. 2008. Slow and fast-reacting antioxidants from berries: their evaluation through the FRAP (ferric reducing antioxidant power) assay. Proceedings of the IXth International Rubus and Ribes Symposium, ISHS. Acta Horticulturae 777. Leuven, Pucón, Chile. December 1-7.

46. Moyer RA, Hummer KE, Finn CE, Frei B, Wrolstad RE. 2002. Anthocyanins, phenolics and antioxidant capacity in diverse small fruits: Vaccinium, Rubus and Ribes. J Agric Food Chem 50: 519-525.

47. Duh PD. 1998. Antioxidant activity of burdock (Arctium lappa Linne): its scavenging effect on free radical and active oxygen. J Am Oil Chem Soc 75: 455-461.

48. Rufián-Henares JA, Morales FJ. 2007. Functional properties of melanoidins: In vitro antioxidant, antimicrobial, and antihypertensive activities. Food Res Int 40: 995-1002.

49. Okawa M, Kinjo J, Nohara T, Ono M. 2001. DPPH (1,1- 
diphenyl-2-picrylhydrazyl) radical scavenging activity of flavonoids obtained from some medicinal plants. Biol Pharm Bull 24: 1202-1205.

50. Mates JM, Sanchez-Jimenez FM. 2000. Role of reactive oxygen in apoptosis: Implications for cancer therapy. Int
J Biochem Cell Biol 32: 157-170.

51. Johnston JW, Harding K, Benson EE. 2007. Antioxidant status and genotypic tolerance of Ribes in vitro cultures cryopreservation. Plant Sci 172: 524-534.

(Received September 4, 2012; Accepted December 8, 2012) 